\title{
Stage I Bladder Cancer with Carcinoma In Situ
}

National Cancer Institute

\section{Source}

National Cancer Institute. Stage I Bladder Cancer with Carcinoma In Situ. NCI Thesaurus. Code C8899.

Stage I bladder carcinoma associated with the presence of bladder carcinoma in situ. 